\title{
Helminth parasite communities of two Physalaemus cuvieri Fitzinger, 1826 (Anura: Leiuperidae) populations under different conditions of habitat integrity in the Atlantic Rain Forest of Brazil
}

\author{
A. Aguiara*, G. M. Toledo ${ }^{a}$, L. A. Anjos ${ }^{b}$ and R. J. Silva ${ }^{a}$ \\ aDepartamento de Parasitologia, Instituto de Biociências, Universidade Estadual Paulista "Júlio de Mesquita Filho" - \\ UNESP, Campus de Botucatu, Distrito de Rubião Junior, s/n, CEP 18618-970, Botucatu, SP, Brazil \\ 'Departamento de Biologia e Zootecnia, Universidade Estadual Paulista "Júlio de Mesquita Filho" - UNESP, \\ Campus Ilha Solteira, Rua Monção, 226, Zona Norte, CEP 15385-000, Ilha Solteira, SP, Brazil \\ *e-mail: aline.aguiarr@gmail.com
}

Received: March 12, 2014 - Accepted: July 25, 2014 - Distributed: November 30, 2015

\begin{abstract}
Adults of Physalaemus cuvieri were collected and necropsied between November 2009 and January 2010. This was carried out in order to report and compare the helminth fauna associated with two populations of this anuran species from the Brazilian Atlantic rain forest under different conditions of habitat integrity. The hosts from the disturbed area were parasitized with five helminth taxa: Cosmocerca parva, Aplectana sp., Physaloptera sp., Rhabdias sp., Oswaldocruzia subauricularis (Nematoda) and Polystoma cuvieri (Monogenea) while those from the preserved area had four helminth taxa: C. parva, Aplectana sp., Physaloptera sp., Rhabdias sp., and Acanthocephalus saopaulensis (Acanthocephala). Prevalence, mean intensity of infection, mean abundance, mean richness, importance index and dominance frequency of helminth component communities were similar in both areas. The helminth community associated with anurans from the disturbed area had higher diversity than that from the preserved area. This study is the first to report on the acanthocephalan parasites of Ph. cuvieri, and the similarity between helminth fauna composition of two host populations under different selective pressures.
\end{abstract}

Keywords: amphibian, Atlantic Rain Forest, component community, helminth fauna, parasites.

\section{Comunidade de helmintos parasitos de duas populações de Physalaemus cuvieri Fitzinger, 1826 (Anura: Leiuperidae) sob diferentes condições de integridade de habitat da Mata Atlântica, Brasil}

\begin{abstract}
Resumo
Adultos de Physalaemus cuvieri foram coletados e necropsiados entre Novembro de 2009 e Janeiro de 2010. Este estudo foi realizado com o objetivo de informar e comparar a helmintofauna associada a duas populações desta espécie de anuro proveniente da Mata Atlântica sob duas condições de integridade de hábitat. Os hospedeiros da área perturbada estavam parasitados por cinco taxa de helmintos: Cosmocerca parva, Aplectana sp., Physaloptera sp., Rhabdias sp., Oswaldocruzia subauricularis (Nematoda) e Polystoma cuvieri (Monogenea), enquanto aqueles da área preservada apresentaram quatro taxa de helmintos: C. parva, Aplectana sp., Physaloptera sp., Rhabdias sp., e Acanthocephalus saopaulensis (Acanthocephala). Prevalência, intensidade média de infecção, abundância média, riqueza média, índice de importância específica e freqüência de dominância da comunidade componente dos helmintos foram similares em ambas as áreas. A comunidade helmíntica associada aos anuros da área perturbada apresentou-se mais diversa do que a encontrada naqueles da área preservada. Este estudo é o primeiro a relatar parasitas acantocéfalos em $P h$. cuvieri, e a semelhança entre a composição da helmintofauna de duas populações hospedeiras sob diferentes pressões seletivas.

Palavras-chave: anfíbios, Mata Atlântica, comunidade componente, helminto fauna, parasitas.
\end{abstract}

\section{Introduction}

The Atlantic rain forest harbours the greatest diversity of anurans in Brazil, approximately 180 species of amphibians (Haddad, 1998; Haddad and Prado, 2005). However, due to the constant environmental degradation and forest fragmentation this high diversity is threatened
(Young et al., 2001; Eterovick et al., 2005; Lips et al., 2005), which makes this biome one of the 10 hotspots of world biodiversity (Myers et al., 2000; Mittermeier et al., 2005). The Atlantic rain forest in São Paulo State has been substantially affected by forest fragmentation because 
prolonged intense exploitation of natural resources (Myers et al., 2000; Mittermeier et al., 2005). Nevertheless, continuous strips of forest still exist in state parks such as the Parque Estadual da Serra do Mar - Núcleo Santa Virgínia (Fundação SOS Mata Atlântica, 2008).

In this context of habitat fragmentation, parasites and predators are some of the first species to be affected by habitat fragmentation, mainly in relation to their distribution and abundance (Gibb and Hochuli, 2002; Laurance et al., 2002); however, the knowledge of those the dynamics of these changes is not well poorly known understood (McCallum and Dobson, 2002). According to McCallum and Dobson (1995), the parasites, like their hosts, also have great ecological importance and contribute to the maintenance of diversity.

Apart from habitat fragmentation (Hartvigsen and Halvorsen, 1994; Poulin and Morand, 1999), factors such as host biology (Aho, 1990; Hamann et al., 2006) and the composition of the host fauna can influence the composition of parasite communities (Poulin and Mouillot, 2003).

In anthropogenic environments, characterized by low biodiversity, parasites with heteroxenic life cycles have little chance of finding the host and completing their life cycle. In this case, it is expected that parasites with monoxenic life cycles are more prevalent. On the other hand, in preserved environments, with high biodiversity, the parasites with heteroxenic life cycles parasite species can be biologically successful because of the presence of hosts that are necessary for their life cycle (Gibb and Hochuli, 2002; Laurance et al., 2002; McKenzie, 2007).

Physalaemus cuvieri, popularly known as "Frog-dog", is an anuran species of small size (approximately $2.75 \mathrm{~cm}$ ) and widely distribution, ranging from northeastern to mid-western and southern Brazil, and parts of Uruguay, Paraguay and Argentina (Haddad et al., 2008; Frost, 2013). It is mainly nocturnal and reproduces in small water bodies of water within open areas, present in all Brazilian biomes (Dixo and Verdade, 2006; Pombal and Haddad, 2007).

This study aims to characterize the composition of helminth communities associated with populations of Ph. cuvieri from two Brazilian Atlantic rain forest sites under different conditions of habitat integrity: a rural area with pastures and forest fragments and a preserved forest area.

\section{Material and Methods}

\subsection{Study area and collection of amphibian hosts}

In November 2009 and January 2010, 43 specimens of Ph. cuvieri were collected (permission granted through SISBIO, the Brazilian Biodiversity Information System - license no. 18240-1) at two contrasting areas of Atlantic rain forest in São Paulo State, Brazil: 21 specimens in the disturbed area and 22 in the preserved area. The disturbed area is located in the São Luiz do Paraitinga (SLP) municipality $\left(23^{\circ} 13^{\prime} \mathrm{S} ; 45^{\circ} 18^{\prime} \mathrm{W}\right)$ and it is characterized by a mosaic of pastures and forest fragments. The preserved area is located in the Serra do Mar State Park - Núcleo Santa Virgínia (NSV) $\left(23^{\circ} 24^{\prime} \mathrm{S}\right.$; $\left.45^{\circ} 03^{\prime} \mathrm{W}\right)$, belonging to the municipalities São Luís do Paraitinga, Cunha, Ubatuba and Natividade da Serra. Both locations are in the Serra do Mar region known as Alto do Rio Paraíba - between the Paraíba do Sul river valley and the northern coast of São Paulo State. The region has a mean altitude of about $742 \mathrm{~m}$ and is characterized by a humid temperate climate with a dry winter and hot summer (CEPAGRI, 2008). The frogs were captured during visual searches at night; afterwards, they were killed with sodium thiopental solution (Thiopentax ${ }^{\circledR}$ ), necropsied and all organs were examined in search of helminths.

\subsection{Parasitological procedures}

The helminths found were collected, fixed in alcohol-formaldehyde-acetic acid solution and preserved in $70 \%$ ethyl alcohol. The monogenoids were fixed under coverslips, applying slight pressure. For species identification, nematodes were cleared with lactophenol and monogenoids and acanthocephalans were stained with carmine and cleared with creosote, and analysed in a computerized image analysis system (Qwin Lite 3.1; Leica Microsystems, Wetzlar, Germany). Identification was based on Vaucher (1990), Vicente et al. (1991), Smales (2007), Anderson et al. (2009) and Gibbons (2010). The helminth parasites were deposited in the Helminthological Collection of the Biosciences Institute in Botucatu (CHIBB), Department of Parasitology, Universidade Estadual Paulista.

\subsection{Data analysis}

The ecological descriptors of parasitism - prevalence, mean abundance (MA) and mean intensity of infection (MII) - were calculated according to Bush et al. (1997). The importance index, an integrated index, was calculated by the sum of the prevalence value and relative abundance followed by multiplication by 100 (Bursey et al., 2001). This index is an overall estimate of the influence of a species within a community.The dominance frequency of each component from parasite infracommunities was calculated according to Rohde et al. (1995) and it is represented by the number of times that a parasite species is dominant in the total of hosts analysed. The $\mathrm{Z}$ test was used to compare the prevalences and the Mann-Whitney test was used to compare the abundances and the MII between populations. Both tests were calculated using Sigma-Stat 3.1 software. The Brillouin index was used for helminth fauna diversity where we excluded from the calculation the immature helminths, such as unidentified larvae and cysts, and female specimens of cosmocercid nematodes, since we could not identify all these nematodes at the species level. The diversity index was used calculated for helminth fauna associated with the two populations of anurans with Past software -2.15 version.

\section{Results}

The overall prevalence was $90.9 \%$ in the NSV sample (20 individuals were infected by at least one parasite), and $85.7 \%$ (18 individuals were parasitized) in the SLP sample, and did not differ between localities $(Z=0.056 ; p=0.956)$. 
The frog population in the preserved area (NSV) had an MII of $4.9 \pm 0.8$ (range 1-13), an MA of $4.4 \pm 0.8$ (range $0-13$ ) and mean helminth richness per host (MR) of $1.5 \pm 0.1$, whereas frogs from the disturbed area (SLP) had an MII of $5.7 \pm 1.1$ (range 2-19), an MA of $4.9 \pm 1.0$ (range 0 -19) and an MR of $1.4 \pm 0.2$ (Table 1). There were no differences between the two areas for either in MII (Mann-Whitney $\mathrm{U}=367.5 ; \mathrm{p}=0.64)$, MA $(\mathrm{U}=466.5 ; \mathrm{p}=0.90)$ or $\mathrm{MR}$ $(\mathrm{U}=341.0 ; \mathrm{p}=0.78)$ between the two areas.

The Ph. cuvieri specimens collected in NSV were parasitized by nematodes and an acanthocephalan: one Aplectana sp., 10 Cosmocerca parva Travassos,

Table 1. Prevalence, mean abundance and mean intensity of infection (expressed as means with standard error), total richness and mean richness per host of helminth parasites of Physalaemus cuvieri from Núcleo Santa Virgínia (NSV) and from São Luis do Paraitinga (SLP), in São Paulo State, Brazil.

\begin{tabular}{lcc}
\hline \multicolumn{1}{c}{ Parameters } & NSV $(\boldsymbol{n}=\mathbf{2 2})$ & SLP $(\boldsymbol{n}=\mathbf{2 1})$ \\
\hline Prevalence $(\%)$ & 90.9 & 85.7 \\
Mean abundance & $4.4 \pm 0.8$ & $4.9 \pm 1.0$ \\
Mean intensity of & $4.9 \pm 0.8$ & $5.7 \pm 1.1$ \\
infection & 5 & 6 \\
Total richness & $1.44 \pm 0.2$ & $1.38 \pm 0.2$ \\
$\begin{array}{l}\text { Mean richness per } \\
\text { host }\end{array}$ & & \\
\hline
\end{tabular}

1925 and 49 unidentified females of cosmocercids (Cosmocercidae), 17 Physaloptera sp. (Physalopteridae), three Rhabdias sp. (Rhabdiasidae), 17 unidentified cysts and larvae and one Acanthocephalus saopaulensis Smales, 2007 (Centrorhynchidae) (Table 2).

The SLP specimens were parasitized by nematodes and a monogenoid: five Aplectana sp., seven C. parva, 65 unidentified females of cosmocercids, 14 Physaloptera sp., four Rhabdias sp., three Oswaldocruzia subauricularis (Rudolphi, 1819) (Molineidae), and four Polystoma cuvieri Vaucher, 1990 (Polystomatidae) (Table 3). Among the samples in which male specimens were present, C. parva and Aplectana sp. were identified; the remaining cosmocercids were females that could not be identified to species due to the difficulty in distinguishing diagnostic morphological characters in females of this nematode group. Physaloptera sp. was found only in larval stages.

Cosmocercid nematodes had the highest importance index (I) values in both host populations studied $\left(\mathrm{I}_{\mathrm{NSV}}=142.8\right.$ and $\left.\mathrm{I}_{\mathrm{SLP}}=155.9\right)$, followed by Physaloptera sp. with $\mathrm{I}_{\mathrm{NSV}}=58.3$ and $\mathrm{I}_{\mathrm{SLP}}=28.0$ (Tables 2 and 3). The cosmocercids were dominant over the other species of the helminth communities, with dominance frequencies of 16 and 15 in NSV and SLP, respectively.

The richness of helminth fauna associated with anurans from NSV was at least five species, and the anurans from SLP presented a richness of at least six helminth species. According to the Brillouin index, the helminth community

Table 2. Prevalence (P), mean intensity of infection (MII) and mean abundance (MA) with standard error (SE), importance index (I), dominance frequency (DF) and site of infection of helminth parasites of Physalaemus cuvieri $(\mathrm{n}=22)$ from Núcleo Santa Virgínia, São Paulo State, Brazil.

\begin{tabular}{|c|c|c|c|c|c|c|}
\hline Parasite & $\mathbf{P}(\%)$ & $\mathrm{MII} \pm \mathrm{SE}$ & $\mathrm{MA} \pm \mathrm{SE}$ & I & DF & Site of infection \\
\hline \multicolumn{7}{|l|}{ Nematoda } \\
\hline Cosmocercidae & 81.8 & $3.3 \pm 0.5$ & $2.7 \pm 0.5$ & 142.8 & 16 & SI, LI, CAV, LUN \\
\hline Unidentified cysts & 9.1 & $7.5 \pm 3.5$ & $0.7 \pm 0.5$ & 24.4 & 1 & STO \\
\hline Unidentified larvae & 4.5 & 2 & $0.1 \pm 0.1$ & 6.6 & 0 & SI, LI \\
\hline Physaloptera sp. & 40.9 & $1.9 \pm 0.3$ & $0.8 \pm 0.2$ & 58.3 & 1 & STO \\
\hline Rhabdias sp. & 9.1 & $1.5 \pm 0.5$ & $0.1 \pm 0.1$ & 12.1 & 1 & LUN \\
\hline \multicolumn{7}{|l|}{ Acanthocephala } \\
\hline $\begin{array}{l}\text { Acanthocephalus } \\
\text { saopaulensis }\end{array}$ & 4.5 & 1 & $0.04 \pm 0.04$ & 5.6 & 0 & CAV \\
\hline
\end{tabular}

SI - small intestine; LI - large intestine; CAV - body cavity; LUN - lungs; STO - stomach.

Table 3. Prevalence (P), mean intensity of infection (MII) and mean abundance (MA) with standard error (SE), importance index (I), dominance frequency (DF) and site of infection of helminth parasites of Physalaemus cuvieri $(\mathrm{n}=21)$ from São Luis do Paraitinga, São Paulo State, Brazil.

\begin{tabular}{|c|c|c|c|c|c|c|}
\hline Parasite & $\mathbf{P}(\%)$ & $\mathrm{MII} \pm \mathrm{SE}$ & $\mathbf{M A} \pm \mathbf{S E}$ & I & DF & $\begin{array}{c}\text { Site of } \\
\text { infection }\end{array}$ \\
\hline \multicolumn{7}{|l|}{ Nematoda } \\
\hline Cosmocercidae & 80.9 & $4.5 \pm 1$ & $3.7 \pm 0.9$ & 155.9 & 15 & STO, SI, LI \\
\hline Physaloptera sp. & 14.3 & $4.7 \pm 3.2$ & $0.7 \pm 0.5$ & 28.0 & 2 & STO \\
\hline Rhabdias sp. & 9.5 & $2 \pm 0$ & $0.2 \pm 0.1$ & 13.4 & 0 & LUN \\
\hline Oswaldocruzia subauricularis & 4.8 & 3 & $0.1 \pm 0.1$ & 7.7 & 0 & SI \\
\hline \multicolumn{7}{|l|}{ Monogenea } \\
\hline Polystoma cuvieri & 14.3 & $1.3 \pm 0.3$ & $0.2 \pm 0.1$ & 18.3 & 1 & GB, UB \\
\hline
\end{tabular}


Table 4. Comparison of mean abundance (MA) and mean intensity of infection (MII) (presented with standard error; SE) and prevalence of helminths of Physalaemus cuvieri from Núcleo Santa Virgínia (NSV) and São Luis do Paraitinga (SLP).

\begin{tabular}{lcccc}
\hline & NSV & SLP & Test & p \\
\hline Cosmocercidae & & & & 0.51 \\
MA \pm SE & $2.7 \pm 0.5$ & $3.7 \pm 0.9$ & $U=489.5$ & 0.34 \\
MII \pm SE & $3.3 \pm 0.5$ & $4.5 \pm 1.0$ & $U=335.5$ & 0.75 \\
Prevalence (\%) & 81.8 & 80.9 & $Z=-0.3$ & 0.16 \\
Physaloptera sp. & & & & 0.50 \\
MA \pm SE & $0.8 \pm 0.2$ & $0.7 \pm 0.5$ & $U=403.5$ & 0.11 \\
MII \pm SE & $1.9 \pm 0.3$ & $4.7 \pm 3.2$ & $U=25.5$ & \\
Prevalence (\%) & 40.9 & 14.3 & $Z=1.6$ & 0.97 \\
Rhabdias sp. & & & & 0.40 \\
MA \pm SE & $0.1 \pm 0.1$ & $0.2 \pm 0.1$ & $U=464.0$ & 0.64 \\
MII \pm SE & $1.5 \pm 0.5$ & $2.0 \pm 0$ & $U=8.0$ & $Z=-0.5$ \\
Prevalence (\%) & 9.1 & 9.5 & & \\
\hline
\end{tabular}

diversity $(\mathrm{H})$ from NSV frogs $(\mathrm{H}=0.97)$ was lower than that from SLP frogs $(\mathrm{H}=1.42)$.

The helminths shared by the two $P h$. cuvieri populations were cosmocercid nematodes, Physaloptera sp. larvae and Rhabdias sp. So, we applied the $\mathrm{Z}$ test and the Mann-Whitney test to compare the ecological parameters of shared parasites between localities, and we did not find significant differences between prevalence, MII and MA of parasites associated with these Ph. cuvieri populations (Table 4).

\section{Discussion}

The $P$ h. cuvieri populations studied presented a relatively high parasite richness (four taxa from the preserved area and five taxa from the disturbed area) when compared with the helminth faunas associated with other species of Physalaemus, such as Physalaemus signifer (Girard, 1853), with three nematode species, and Physalaemus soaresi Izecksohn, 1965, with two nematode species (Fabio, 1982). On the other hand, Hamann and González (2009) and González and Hamann (2010) studied the helminths associated with Physalaemus santafecinus Barrio, 1965 and found three digenean taxa (in tadpoles) and four nematode taxa (in adults), respectively. For Physalaemus albonotatus (Steindachner, 1864), González and Hamann (2012) reported six nematode taxa.

Of all helminths recorded in the present study, only the monogenoid Polystoma cuvieri and the nematode Cosmocerca parva were previously reported in Ph. cuvieri (Vaucher, 1990; Santos and Amato, 2012, 2013). Aplectana sp. and Physaloptera sp. were previously reported in other species of this genus (Fábio, 1982; González and Hamann, 2010, 2012), corroborating the generalist pattern of the helminth communities associated with anurans (Aho, 1990; Bursey et al., 2001). There are no previous records of the occurrence of Rhabdias sp., O. subauricularis and A. saopaulensis parasitizing anurans of the genus Physalaemus in the South American continent. Physalaemus cuvieri is thus a new host for all helminth taxa found in the present study, excluding the monogenoid Po. cuvieri and the nematode C. parva.

Among the helminths found in both $P h$. cuvieri populations, the acanthocephalan $A$. saopaulensis and the monogenoid Po. cuvieri are the least frequently reported in amphibians (Vaucher, 1990; Smales, 2007). The acanthocephalan transmission to anurans occurs by ingestion of invertebrates parasitized with cystacants that infect the gastrointestinal tract (Kennedy, 2006), making the anuran a definitive or paratenic host (Smales, 2007; Pinhão et al., 2009; Santos and Amato, 2010). The monogenoids, parasites of amphibian urinary bladders, have monoxenic cycles and high specificity with the host. They infect the individual by the gills when they are still in the tadpole phase. After the host's metamorphosis, they migrate to the urinary bladder and reproduce (Smyth, 1994).

Cosmocerca parva and O. subauricularis are transmitted directly via infective larvae that penetrate actively in the host's tegument, and adults later can reach the gastrointestinal tract (Anderson, 2000). The lung infection by Rhabdias spp. occurs similarly, but only by parthenogenetic females that alternate between free-living and parasitic life cycles in anurans (Anderson, 2000). Aplectana spp. are also transmitted directly, but the infection occurs by the ingestion of eggs containing infective larvae that reach the gastrointestinal tract and then mature (Anderson, 2000). Physaloptera sp. larvae are found in the stomach mucosa of anurans that ingest insects infected by larvae; the anuran can be a definitive or paratenic host (Anderson, 2000; González and Hamann, 2006).

In the helminth communities associated with the two Ph. cuvieri populations, cosmocercid nematodes had the highest prevalence, MA and dominance frequency (Tables 1 and 2), corroborating the generalist pattern of these anuran helminths (Bursey et al., 2001). This is associated with the fact that these species can easily infect a host in a direct way, not requiring intermediate hosts to complete their biological cycle (Anderson, 2000; Hamann et al., 2006). 
The high prevalence and abundance of Cosmocercidae, Physaloptera sp. and Rhabdias sp. may have been responsible for the observed similarity between the two parasite communities (Poulin, 2007), which presented no statistical difference between the overall prevalence, MAs and MIIs of component communities. Among the helminths found in anurans from SLP and NSV, only Physaloptera sp. and A. saopaulensis have heteroxenic life cycles, in which parasites complete their biological cycle by trophic transmission, requiring an invertebrate as an intermediate host (Anderson, 2000; Kennedy, 2006). The importance of parasites as indicators of environmental quality has been shown in some studies (Gibb and Hochuli, 2002; Laurance et al., 2002; Hamann et al., 2006; McKenzie, 2007) and only richness is not a decisive indicator of environmental conditions (Aho, 1990). The component community and the biology of helminths allow the understanding of the dynamics among parasites, hosts and environment (Poulin, 2007). The frogs from the preserved area (NSV) had a lower helminth richness than those from the disturbed area (SLP), but were parasitized with two species that require invertebrates as the intermediate host. Preserved environments may have a more diverse invertebrate fauna, increasing the chances of the parasite finding its host.

There were no significant differences between the descriptors of parasitism and the helminth fauna composition associated with the two populations of Ph. cuvieri; however, according to the Brillouin diversity index, the helminth community associated with frogs from the disturbed area (SLP) had higher diversity than that of the preserved area (NSV). This can be related to the low immune system of the anurans from the disturbed area (SLP), making them more susceptible to parasitism, or the long exposure of the host to the parasites, or the different selection pressures that regulate the helminth community (Aho, 1990; Rollins-Smith, 2001; Todd, 2007; Poulin, 2007).

This research is the first report concerning helminth community associated with $\mathrm{Ph}$. cuvieri, an anuran with wide distribution in South America, living in the Atlantic rain forest and other biomes such as Brazilian savanna (Cerrado), representing an important study about this anuran species.

\section{Acknowledgements}

The authors are grateful to the Fundação de Amparo à Pesquisado Estado de São Paulo (FAPESP) for financial support (2008/50417-7, 2008/58180-6, 09/15104-0).

\section{References}

AHO, J.M., 1990. Helminth communities of amphibians and reptiles: comparative approaches to understanding patterns and processes. In: G.W. ESCH, A.O. BUSH and J.M. AHO, eds. Parasite communities: patterns and processes. London: Chapman and Hall, pp. 157-190.
ANDERSON, R.C., 2000. Nematode parasites of vertebrates: their development and transmission. 2nd ed. London: CABI International.

ANDERSON, R.C., CHABAUD, A.G. and WILLMOTT, S., 2009. Keys to the nematode parasites of vertebrates. London: CABI Publishing.

BURSEY, C.R., GOLDBERG, S.R. and PARMELEE, J.R., 2001. Gastrointestinal helminths of 51 species of anurans from Reserva Cuzco Amazónico, Peru. Comparative Parasitology, vol. 68 , pp. 21-35.

BUSH, A.O., LAFFERTY, K.D., LOTZ, J.M. and SHOSTAK, A.W., 1997. Parasitology meets ecology on its own terms: Margolis et al. revisited. The Journal of Parasitology, vol. 83, no. 4, pp. 575-583. http://dx.doi.org/10.2307/3284227. PMid:9267395.

CENTRO DE PESQUISAS METEOROLÓGICAS E CLIMÁTICAS APLICADAS À AGRICULTURA - CEPAGRI, 2008 [viewed 29 October 2008]. Clima dos municípios paulistas: São Luís do Paraitinga [online]. Available from: http://www.cpa.unicamp. br/outras-informacoes/clima_muni_562.html.

DIXO, M. and VERDADE, V.K., 2006. Herpetofauna de serrapilheira da Reserva Florestal de Morro Grande, Cotia (SP). Biota Neotropica, vol. 6, no. 2, pp. 1-14. http://dx.doi.org/10.1590/ S1676-06032006000200009.

ETEROVICK, P.C., CARNAVAL, A.C.O.Q., BORGES-NOJOSA, D.M., SILVANO, D.L., SEGALLA, M.V. and SAZIMA, I., 2005. Amphibian declines in Brazil: an overview. Biotropica, vol. 37, no. 2, pp. 66-179. http://dx.doi.org/10.1111/j.1744-7429.2005.00024.x.

FABIO, S.P., 1982. Helmintos de populações simpátricas de algumas espécies de anfíbios anuros da família Leptodactylidae. Arquivos da Universidade Federal Rural do Rio de Janeiro, vol. 5, pp. 69-83.

FROST, D.R., 2013 [viewed 25 January 2013]. Amphibian species of the world: an online reference. Version 5.5. Electronic database [online]. New York: American Museum of Natural History. Available from: http://research.amnh. org/vz/herpetology/amphibia/.

FUNDAÇÃO SOS MATAATLÂNTICA, 2008 [viewed 10 October 2008]. Atlas dos remanescentes florestais da Mata Atlântica, periodo de 1995-2000 [online]. Available from: http://www. sosmatatlantica.org.br.

GIBB, H. and HOCHULI, D.F., 2002. Habitat fragmentation in an urban environment: large and small fragments support different arthropod assemblages. Biological Conservation, vol. 106, no. 1, pp. 91-100. http://dx.doi.org/10.1016/S0006-3207(01)00232-4.

GIBBONS, L.M., 2010. Keys to the nematode parasites of vertebrates. London: CABI Publishing.

GONZÁLEZ, C.E. and HAMANN, M.I., 2006. Helmintos parásitos de Leptodactylus bufonius Boulenger, 1894 (Anura: Leptodactylidae) de Corrientes, Argentina. Revista Española de Herpetología, vol. 20, pp. 39-46.

GONZÁLEZ, C.E. and HAMANN, M.I., 2010. First report of nematode parasites of Physalaemus santafecinus (Anura: Leiuperidae) from Corrientes, Argentina. Revista Mexicana de Biodiversidad, vol. 81, pp. 677-687.

GONZÁLEZ, C.E. and HAMANN, M.I., 2012. First report of nematode parasites of Physalaemus albonotatus (Steindachner, 1864) (Anura: Leiuperidae) from Corrientes, Argentina. Neotropical Helminthology, vol. 6, pp. 9-23.

HADDAD, C.F.B. and PRADO, C.P.A., 2005. Reproductive modes in frogs and their unexpected diversity in the Atlantic 
Forest of Brazil. Bioscience, vol. 55, no. 3, pp. 207-217. http:// dx.doi.org/10.1641/0006-3568(2005)055[0207:RMIFAT]2.0.CO;2.

HADDAD, C.F.B., 1998. Biodiversidade dos anfíbios no Estado de São Paulo. In: R.M.C. CASTRO, ed. Biodiversidade do Estado de São Paulo, Brasil: síntese do conhecimento ao final do século $X X$. São Paulo: FAPESP, pp. 15-26. Vertebrados, 6 .

HADDAD, C.F.B., TOLEDO, L.F. and PRADO, C.P.A., 2008. Anfibios da Mata Atlântica. São Paulo: Editora Neotropica.

HAMANN, M.I. and GONZÁLEZ, C.E., 2009. Larval digenetic trematodes in tadpoles of six amphibian species from northeastern Argentina. The Journal of Parasitology, vol. 95, no. 3, pp. 623628. http://dx.doi.org/10.1645/GE-1738.1. PMid:19045934.

HAMANN, M.I., KEHR, A.I. and GONZÁLEZ, C.E., 2006. Species affinity and infracommunity ordination of helminths of Leptodactylus chaquensis (Anura: Leptodactylidae) in two contrasting environments from Northeastern Argentina. The Journal of Parasitology, vol. 92, no. 6, pp. 1171-1179. http:// dx.doi.org/10.1645/GE-862R1.1. PMid:17304791.

HARTVIGSEN, R. and HALVORSEN, O., 1994. Spatial patterns in the abundance and distribution of parasites of freshwater fish. Parasitology Today (Personal Ed.), vol. 10, no. 1, pp. 28-31. http:// dx.doi.org/10.1016/0169-4758(94)90354-9. PMid:15275564.

KENNEDY, C.R., 2006. Ecology of the Acanthocephala. New York: Cambridge University Press.

LAURANCE, W.F., LOVEJOY, T.E., VASCONCELOS, H.L., BRUNA, E.M., DIDHAM, R.K., STOUFFER, P.C., GASCON, C., BIERREGAARD, R.O., LAURANCE, S.G. and SAMPAIO, E., 2002. Ecosystem decay of Amazonian forest fragments: a 22-year investigation. Conservation Biology, vol. 16, no. 3, pp. 605-618. http://dx.doi.org/10.1046/j.1523-1739.2002.01025.x.

LIPS, K.R., BURROWES, P.A., MENDELSON, J.R. and PARRA-OLEA, G., 2005. Amphibian declines in Latin America: widespread population declines, extinctions, and impacts. Biotropica, vol. 37, no. 2, pp. 163-165. http://dx.doi.org/10.1111/j.17447429.2005.00023.x.

MCCALLUM, H. and DOBSON, A., 1995. Detecting disease and parasite threats to endangered species and ecosystems. Trends in Ecology \& Evolution, vol. 10, no. 5, pp. 190-194. http://dx.doi. org/10.1016/S0169-5347(00)89050-3. PMid:21237000.

MCCALLUM, H. and DOBSON, A., 2002. Disease, habitat fragmentation and conservation. Proceedings. Biological Sciences, vol. 269 , no. 1504 , pp. 2041-2049. http://dx.doi.org/10.1098/ rspb.2002.2079. PMid:12396504.

MCKENZIE, V.J., 2007. Human land use and patterns of parasitism in tropical amphibian hosts. Conservation Biology, vol. 137, no. 1, pp. 102-116. http://dx.doi.org/10.1016/j.biocon.2007.01.019.

MITTERMEIER, R.A., GIL, P.R., HOFFMANN, M., PILGRIM, J., BROOKS, J., MIITERMEIER, C.G., LAMOURUX, J. and FONSECA, G.A.B., 2005. Hotspots revisited: earth's biologically richest and most endangered terrestrial ecoregions. Washington, D.C.: Conservation International. vol. 4, 392 p.

MYERS, N., MITTERMEIER, R.A., MITTERMEIER, C.G., FONSECA, G.A.B. and KENT, J., 2000. Biodiversity hotspots for conservation priorities. Nature, vol. 403, no. 6772, pp. 853-858. http://dx.doi.org/10.1038/35002501. PMid:10706275.

PINHÃO, R., WUNDERLICH, A.C., ANJOS, L.A. and SILVA, R.J., 2009. Helminths of toad Rhinella icterica (Bufonidae) from the municipality of Botucatu, São Paulo State, Brazil. Neotropical Helminthology, vol. 3, pp. 35-40.
POMBAL, J.P., and HADDAD, C.F.B., 2007. Estratégias e modos reprodutivos em anuros. In: L.B. NASCIMENTO and P.M.E. OLIVEIRA, eds. Herpetologia no Brasil II. São Paulo: Sociedade Brasileira de Herpetologia, pp. 101-116.

POULIN, R. and MORAND, S., 1999. Geographical distances and the similarity among parasite communities of conspecific host populations. Parasitology, vol. 119, no. Pt 4, pp. 369-374. http://dx.doi.org/10.1017/S0031182099004795. PMid:10581615.

POULIN, R. and MOUILLOT, D., 2003. Parasite specialization from a phylogenetic perspective: a new index of host specificity. Parasitology, vol. 126, no. Pt 5, pp. 473-480. http://dx.doi. org/10.1017/S0031182003002993. PMid:12793652.

POULIN, R., 2007. Are there general laws in parasite ecology? Parasitology, vol. 134, no. Pt 6, pp. 763-776. http://dx.doi. org/10.1017/S0031182006002150. PMid:17234043.

ROHDE, K., HAYWARD, C. and HEAP, M., 1995. Aspects of the ecology of metazoan ectoparasites of marine fishes. International Journal for Parasitology, vol. 25, no. 8, pp. 945-970. http://dx.doi. org/10.1016/0020-7519(95)00015-T. PMid:8550295.

ROLLINS-SMITH, L.A., 2001. Neuroendocrine-immune system interactions in amphibians: implications for understanding global amphibian declines. Immunologic Research, vol. 23, no. 2-3, pp. 273-280. http://dx.doi.org/10.1385/IR:23:2-3:273. PMid:11444392.

SANTOS, V.G.T. and AMATO, S.B., 2010. Rhinella fernandezae (Anura, Bufonidae) a paratenic host of Centrorhynchus sp. (Acanthocephala, Centrorhynchidae) in Brazil. Revista Mexicana de Biodiversidad, vol. 81, pp. 53-56.

SANTOS, V.G.T. and AMATO, S.B., 2012. Polystoma cuvieri (Monogenea, Polystomatidae) in Physalaemus cuvieri (Anura, Leiuperidae) in Southern Brazil. Neotropical Helminthology, vol. 6, pp. 1-7.

SANTOS, V.G.T. and AMATO, S.B., 2013. Species of Cosmocerca (Nematoda, Cosmocercidae) in Anurans from Southern Santa Catarina State, Brazil. Comparative Parasitology, vol. 80, no. 1, pp. 123-129. http://dx.doi.org/10.1654/4608.1.

SMALES, L.R., 2007. Acanthocephala in amphibians (Anura) and reptiles (Squamata) from Brazil and Paraguay with description of a new species. The Journal of Parasitology, vol. 93, no. 2, pp. 392-398. http://dx.doi.org/10.1645/GE-937R.1. PMid:17539424.

SMYTH, J.D., 1994. Introduction to animal parasitology. London: Cambridge University Press.

TODD, B.D., 2007. Parasites lost? An overlooked hypothesis for the evolution of alternative reproductive strategies in amphibians. American Naturalist, vol. 170, no. 5, pp. 793-799. http://dx.doi. org/10.1086/521958. PMid:17926300.

VAUCHER, C., 1990. Polystoma cuvieri n. sp. (Monogenea: Polystomatidae) a parasite of the urinary bladder of the Leptodactylid frog Physalaemus cuvieri in Paraguay. The Journal of Parasitology, vol. 76, no. 4, pp. 501-504. http://dx.doi.org/10.2307/3282828. PMid:2380858.

VICENTE, J.J., RODRIGUES, H.O., GOMES, D.C. and PINTO, R.M., 1991. Nematóides do Brasil - parte II: Nematóides de anfíbios. Revista Brasileira de Zoologia, vol. 7, no. 4, pp. 549-626. http:// dx.doi.org/10.1590/S0101-81751990000400015.

YOUNG, B.E., LIPS, K.R., REASER, J.K., IBÁÑEZ, R., SALAS, A.W., CEDEÑO, J.R., COLOMA, L.A., RON, S., LA MARCA, E., MEYER, J.R., MUÑOZ, A., BOLAÑOS, F., CHAVES, G. and ROMO, D., 2001. Population declines and priorities for amphibian conservation in Latin America. Conservation Biology, vol. 15 , no. 5, pp. 1213-1223. http://dx.doi.org/10.1046/j.15231739.2001.00218.x. 